\title{
The Eco-Innovation Variables which Influence the Performance of Creative Industries Center of Natural Stone Crafts
}

\author{
${\text { Murti Astuti }{ }^{*} \text {, Pratikto Prawoto }}^{2}$, Yudy Surya Irawan², Sugiono Sugiono ${ }^{1}$ \\ 1 Department of Industrial Engineering, Universitas Brawijaya, Veteran Street, Malang 65145, Indonesia \\ 2 Department of Mechanical Engineering, Universitas Brawijaya, Veteran Street, Malang 65145, Indonesia \\ * Corresponding author's e-mail: murti4stuti@gmail.com
}

\begin{abstract}
This study investigates the eco-innovation variable which has the significant effect on creative industries center's performance of marble and natural stone craft sector in Tulungagung, Indonesia. The object of the study is the creative industries center with the non-renewable raw material. Mostly, the companies are in form of small and medium-sized enterprises (SMEs) which is 'passive eco-innovator' and their eco-innovation variables have not been investigated before in terms of their influence on their performance. The respondents were 81 craftsmen taken from the population. The data were collected through questionnaires which were tested, processed and analyzed by using Consistent Partial Least Square (PLSc). The eco-innovation variables which significantly effect on innovative performance are eco-organizational innovation and eco-product innovation. Eco-process innovation and eco-marketing innovation don't directly affect on innovative performance, but its significant effect on eco-product innovation may influence innovative performance. Improving innovative performance will impact on financial performance through improvement of production performance, but market performance does not significantly affect financial performance. The findings of this study could be a reference for creative industries center's of marble and natural stone craft sector to prioritize which type of eco-innovation should be improved so that its impact on performance is more significant.
\end{abstract}

Keywords: creative industries center, eco-innovation, innovative performance, PLSc

\section{INTRODUCTION}

Tulungagung district is known as the biggest marble and natural stone craft industries center in Indonesia. Besides display crafts, craftsmen in Tulungagung also produce items that are functional as a complement to building architecture, such as marble for tiles, wall mosaic, overlay, sink, bathtub, whirlpool, bathroom material, park chair and table, dining table, park lamp, water wall, suiseki and etc (see Figure 1). The largest market of the product is the export market in Europe, America, and Asia.

This creative industry sustainability will depend much on innovation. The innovation that can improve business performance and also cares about the environment is eco-innovation which is defined as a process to develop the products and the process to reduce the negative impact of using the resources (Kemp \& Pearson, 2007). The eco-innovation application does not only solve the serious global environmental problem but also to increase the competitive excellence of a company. It means that with the improvement of consumers' awareness about both products and production process more environmentally friendly, a company which applies eco-innovation will have better competitive excellence compared to other companies (Tessitore et al., 2010). Besides that, there is evidence that eco-innovation does not disturb economy performance both in short-term and in global financial crisis condition (Díaz-García et al., 2015).

In marble and natural stone crafts industries center in Tulungagung, the eco-innovation application is not declared formally and strategically. 


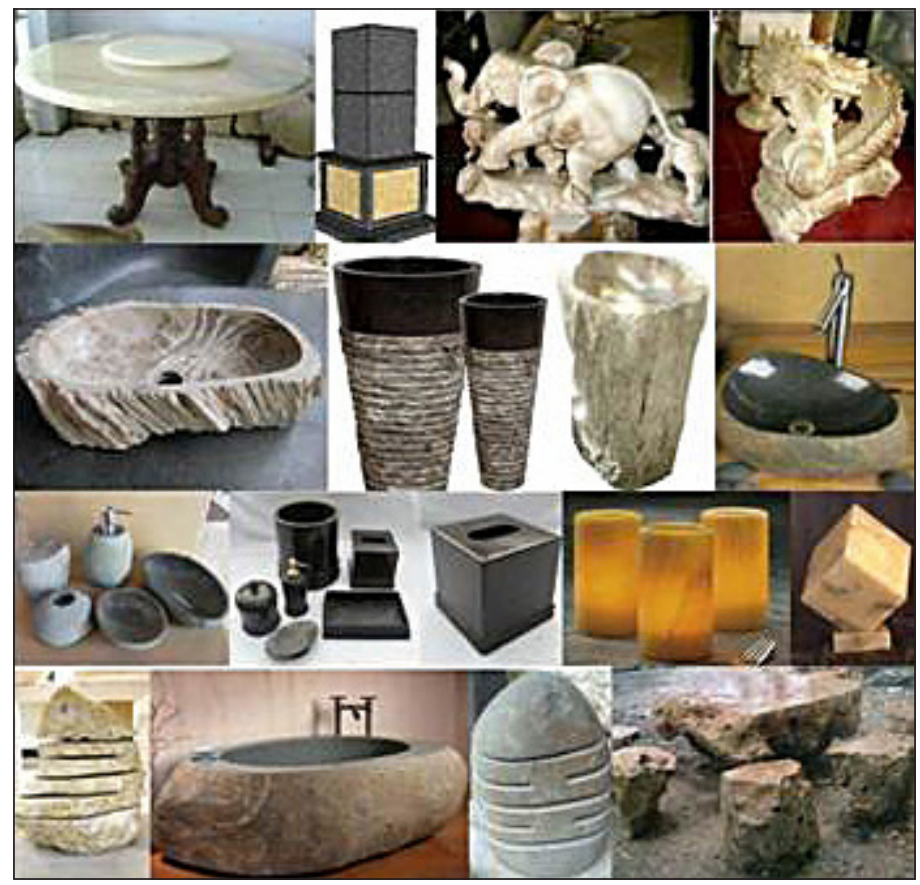

Figure 1. Example of marble and natural stone crafts in Tulungagung industries center

However, the global market demand has been forcing the craftsmen to apply eco-innovation practices. According to Kemp \& Pearson (2007), this kind of eco-innovation practices is called as 'passive eco-innovator' which are implementing eco-innovation without using a specific strategy to eco-innovate.

In the practice, there are different types of eco-innovation (OECD, 2005). In order to develop an effective eco-innovation program, a decision maker should understand the interdependence relationship between different types of ecoinnovation (Cheng et al., 2014). This study aims to provide a holistic analysis of the impact of ecoinnovation by investigating the interrelationship between different types of eco-innovation and its impact on the performance of marble and natural stones crafts industries center, because according to Cheng (Cheng et al., 2014) it is not effective to conduct an eco-innovation program without a holistic perspective.

\section{Eco-innovation}

Eco-innovation is an attempt to develop process and new products to increase the products' value significantly and minimize the negative impact on the environment (Mcaloone \& Hare, 2014). The eco-innovation application does not only solve the serious global environmental problem but also increase the competitive ex- cellence of a company (Kemp \& Pearson, 2007; Tessitore et al., 2010).

There are four different terms which are used in every literature to describe the innovation which is able to reduce the negative impact on the environment, namely "green innovation", "eco-innovation", "environmental innovation" and "sustainable innovation" (Díaz-García et al., 2015). Compared to other terms, eco-innovation explicitly states that its analysis stage covers along the lifecycle starting from the input until the output in order to reduce resources consumption (Kemp \& Pearson, 2007; Reid \& Miedzinski, 2008).

According to Miedzinski et al. (2013), ecoinnovation means introducing new products or increasing significantly product/service's value, improving the process, organizational changing and new marketing solution which can minimize the use of natural resources (including material, energy, water and soil) and also reducing the release of dangerous substances throughout its life cycle (Miedzinski et al., 2013). MEI (Measuring Eco-Innovation) Project develops innovation definition from OECD Oslo Manual into the ecoinnovation which is defined as a process towards sustainable development through theories and methodological approach to develop both product and process in order to reduce the negative effect of the resources use (Kemp \& Pearson, 2007).

Eco-product innovation is the introduction of new products or significant improvements of 
product's characteristics, such as improvements its technical components and materials (Pujari, 2006). The product innovation can be in form of existing product or service improvement or new product development (Miedzinski et al., 2013).

Eco-process innovation is modifying the organization's operational processes and systems, decreases unit costs of production, produces new or significantly improved eco-products and reduces environmental impacts (Negny et al., 2012). Ecoprocess innovation happens if some output (product and service) can be produced with input as minimum as possible (Kemp \& Pearson, 2007).

Marketing innovation is the implementation of a new marketing method which includes new packaging designs of a product, the new outlet to display the products, promotion and new pricing. The main problem that should be considered in marketing innovation is the opportunity to build a partnership with new marketing channel in order to access previously inaccessible markets ( $\mathrm{O}^{\prime} \mathrm{Hare}$ et al., 2014). From the eco-innovation perspective, the activity of eco-marketing innovation can be in form of adding the environmental aspect in the product promotion such as putting eco-labeling on the product (Miedzinski et al., 2013).

According to Birkinshaw et al. (2008), ecoorganizational innovation refers to the improvement of organizational management process through a new method in business practices. Kemp \& Arundel (1998) conclude that eco-organizational innovation covers training program, economical product design programs, eco-learning techniques, or build management team to handle the environmental problem.

\section{Company performance}

Innovative performance is a combination of overall company achievement as the result of renewal and improvement effort which is done through process innovation, product, organization, and marketing, including eco-innovation (Hagedoorn \& Cloodt, 2003). Therefore, innovative performance is a combination of the constructs of various performance-related indicators, such as new patents, new product inventions, new projects, new processes, new marketing practices and new organizational structures (Gunday et al., 2011; Hagedoorn \& Cloodt, 2003).

Production performance is measured based on the system ability to meet product demand based on the quality requested by the consum- ers, low production cost, production availability (flexibility), production speed and delivery. Marketing performance is scaled based on the increase of costumers' satisfaction, total sales, and market share. Financial performance is measured based on the increase of Return On Sales (profit/total sales), Return On Assets (profit/total assets) and company profit (Cheng et al., 2014; Gunday et al., 2011).

\section{MATERIAL AND METHODS}

\section{Hypotheses formulation}

Hypotheses in this study are formulated based on a conceptual model which is adapted from the study conducted by Gunday et al. (2011) and the findings of the former study on the relationship between any types of eco-innovation with company performance.

According to Murphy \& Gouldson (2000), eco-organizational innovation generally does not reduce the environmental impact directly but facilitates the implementation of eco-marketing, eco-process, and eco-product innovation. Thus, hypotheses are formulated as follows:

- H1: There is a positive relationship between eco-organizational innovation and eco-product innovation.

- H2: There is a positive relationship between eco-organizational innovation and eco-process innovation.

- H3: There is a positive relationship between eco-organizational innovation and eco-marketing innovation.

Ettlie \& Reza (1992) state that any kind of process innovation activities such as using new tools, redefining task specification, and improving information access may facilitate the development of new products. A study conducted by Bigliardi \& Dormio (2009); Raymond \& St-Pierre (2010); Maine et al. (2012) also supports the idea that process innovation with new techniques will increase an ability to add new features on the products to meet the market demand. Therefore, the eco-process innovation improvement really supports eco-product innovation. Hence, Hypothesis 2 for this study is formulated as follow:

- H4: There is a positive relationship between eco-process innovation and eco-product innovation. 
In Oslo Manual (OECD, 2005), it is said that marketing innovation relates tightly with pricing strategy, products packaging design, products distribution and the activities along $4 \mathrm{P}$ lines (product, price, promotion, place) introduced by Kotler et al. (2013). Thus, marketing innovation will influence both production and distribution process. Hence, its hypotheses are formulated as follows:

- H5: There is a positive relationship between eco-marketing innovation and eco-process innovation.

- H6: There is a positive relationship between eco-marketing innovation and eco-product innovation.

In his empirical study, Oke (2007) found that some types of innovations have positive relationships with company's innovative performance. The indirect influence of the 4 types of innovation was hoped to trigger improvement on production and marketing performance through innovative performance mediation. In this case, innovative performance plays an effective role in bringing the positive influence of the innovation on some aspects of company performance such as production performance, marketing performance, and financial performance (Gunday et al., 2011). From the findings of the previous studies, that can be formulated hypothesis as follows:

- H7: There is positive relationship between eco-organizational innovation and innovative performance.

- H8: There is positive relationship between eco-product innovation and innovative performance.

- H9: There is positive relationship between eco-process innovation and innovative performance.

- H10: There is positive relationship between eco-marketing innovation and innovative performance.

According to Koufteros \& Marcoulides (2006), besides the speed aspect and the quality, innovative performance is also related to two other elements of production performance which are flexibility and cost efficiency. Liu et al. (2009) confirm in their empirical study on the positive relationship between operational flexibility and the success of the new products. Meanwhile, Peters (2008) states that not all the innovation process promote cost saving and they enable a company to sell a product with competitive price. Hence, its hypotheses are formulated as follows:
- H11: There is positive relationship between innovative performance and market performance.

- H12: There is positive relationship between innovative performance and production performance.

Production performance as a result of organizational success in increasing speed, quality, flexibility, and doing cost efficiency in daily operation logically may improve marketing position and financial benefit (González-Benito, 2005). Good production performance such as high productivity and fast delivery will increase costumers' satisfaction ( $\mathrm{Li}, 2005)$. Therefore, the hypotheses are can be formulated as follows:

- H13: There is positive relationship between production performance and market performance.

- H14: There is positive relationship between production performance and financial performance.

A good ability in product marketing will increase financial benefit (Li, 2000). For this reason, a hypothesis is formulated as follows:

- H15: There is a positive relationship between market performance and financial performance.

The conceptual model and hypotheses in this study are illustrated in Figure 2.

\section{Measurement development}

The data for eco-innovation were collected by asking questions that were related to indicators of each kind of eco-innovation. Respondents were asked to indicate in Likert scale 1-5 how far the application and the practice of indicators of each eco-innovation related to whether they had implemented them in their business in the last three years. Answer 1 = not implement, 2 = only imitated what was implemented in a national market, $3=$ only imitated what was implemented in the international market, $4=$ developed the innovation which had been implemented and $5=$ implemented an extremely new innovation. There were 4 types of eco-innovation that were investigated. In terms of the question on the company performance, the respondents were asked to answer questions related to performance indicators with 5 points of Likert Scale where answer 1 indicated very unsuccessful, $2=$ unsuccessful, $3=$ fair, 4 $=$ successful, and $5=$ very successful. There are 


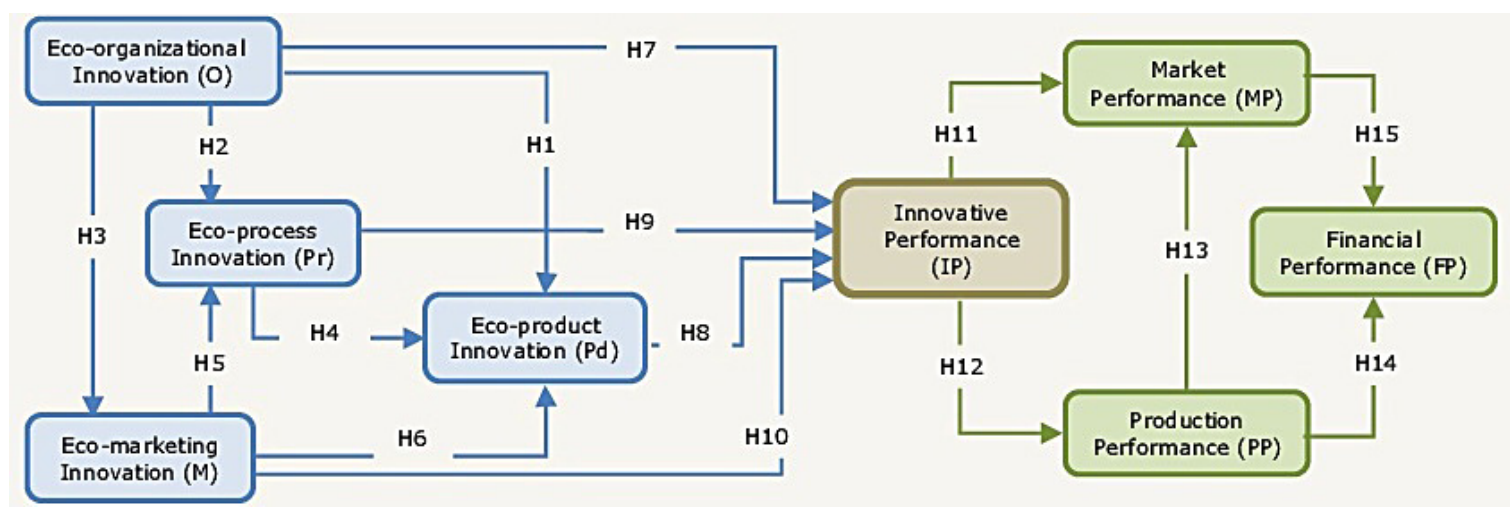

Figure 2. Conceptual model and study hypotheses

four types of company performances that were investigated. The questions related to each indicator of eco-innovation and performance were developed based on the study conducted by Gunday et al. (2011) and Cheng et al. (2014) and reference from Miedzinski et al. (2013).

\section{Sample and data collection}

The study sample was taken from the marble and natural stone handicraft business center in Tulungagung district, Indonesia. There are 120 craftsmen listed. Questionnaires were distributed to owners of small to medium enterprises that are there. The study was conducted in April 2017 until June 2017. From all of the distributed questionnaires, there were 81 of data that could be processed. The problem during data collecting was that many respondents did not have accurately recorded data. Besides that, most craftsmen did not sell their own product. Their products were delivered to the larger industries with subcontract system.

\section{Statistical analysis}

Analysis of Structural Equation Modeling with Partial Least Square approach was used to investigate a predictive relationship between latent variables and also between the latent variable and its construct indicator (Hair et al., 2016; Vinzi et al., 2010). PLS-SEM is more appropriate for small sample size, which is most likely multivariate non-normality. In PLS, the assumption of multinormal distribution is not necessary because can direct estimated uses the bootstrapping technique. Specifically, in this study is used consistent PLS algorithm (Dijkstra \& Henseler, 2015). The consistent PLS (PLSc) algorithm performs a correc- tion of reflective constructs' correlations to make results consistent with a factor-model (Dijkstra 2010; Dijkstra 2014; Dijkstra and Henseler 2015)

To analyze the conceptual model was used the consistent Partial Least Squares (PLSc) technique using the SmartPLS 3.2.7 software (Hair et al., 2017). The analysis of data was started by making a path diagram based on the conceptual model. The next process was to test the measurement model followed by an examination of the structural model (Hair et al., 2017). To test the significance of the path coefficients was used a bootstrapping method with 5000 resamples (Hair et al., 2017).

\section{The evaluation of measurement model (outer model)}

The outer model analysis was conducted to ensure that the indicators used were feasible to be the measurement tool (valid and reliable). To assess the measurement model two types of validity were being examined - first the convergent validity and then the discriminant validity.

Validity test in PLS was calculated using convergent validity which was defined as the correlation between reflective indicator score and its latent variable score by referring to outer loading score, average variance extracted (AVE) and also the composite reliability (CR). From the result (see Table 1), it can be seen that indicators' group of all constructs had fulfilled the convergent validity because the outer loading score of all indicators was $>0.7$; and the score of Cronbach's Alpha, $\rho \mathrm{A}, \mathrm{CR}$ and AVE of each construct was $\geq 0.5$ (Henseler et al., 2016)

So far the discriminant validity can be known by reference to the Fornell and Larcker Criteria (Fornell \& Larcker, 1981). However, there has 
Table 1. Convergent validity, composite reliability and collinearity statistics (VIF)

\begin{tabular}{|c|c|c|c|c|c|c|c|}
\hline Model construct & Indicators & Outer loadings & Cronbach's Alpha & $\rho_{A}$ & CR & AVE & VIF \\
\hline $\begin{array}{l}\text { Eco-organizational innovation } \\
\text { (O) }\end{array}$ & $\begin{array}{l}\text { O1 } \\
\text { O2 } \\
\text { O3 } \\
\text { O4 } \\
\text { O5 } \\
\text { O6 }\end{array}$ & $\begin{array}{l}0.807 \\
0.921 \\
0.838 \\
0.741 \\
0.891 \\
0.881\end{array}$ & 0.939 & 0.942 & 0.939 & 0.720 & $\begin{array}{l}3.637 \\
4.271 \\
3.885 \\
2.841 \\
4.038 \\
2.457\end{array}$ \\
\hline Eco-marketing innovation (M) & $\begin{array}{l}\text { M1 } \\
\text { M2 } \\
\text { M3 } \\
\text { M4 }\end{array}$ & $\begin{array}{l}0.751 \\
0.862 \\
0.872 \\
0.858\end{array}$ & 0.902 & 0.906 & 0.904 & 0.701 & $\begin{array}{l}2.012 \\
2.915 \\
4.185 \\
2.671\end{array}$ \\
\hline Eco-process innovation (Pr) & $\begin{array}{l}\text { Pr2 } \\
\text { Pr3 } \\
\text { Pr4 } \\
\text { Pr5 } \\
\text { Pr6 } \\
\end{array}$ & $\begin{array}{l}0.746 \\
0.821 \\
0.791 \\
0.747 \\
0.784 \\
\end{array}$ & 0.885 & 0.886 & 0.885 & 0.606 & $\begin{array}{l}3.070 \\
3.027 \\
2.871 \\
1.961 \\
1.590 \\
\end{array}$ \\
\hline Eco-product innovation $(\mathrm{Pd})$ & $\begin{array}{l}\mathrm{Pd} 1 \\
\mathrm{Pd} 2 \\
\mathrm{Pd} 3 \\
\mathrm{Pd} 4 \\
\mathrm{Pd} 5 \\
\mathrm{Pd} 6\end{array}$ & $\begin{array}{l}0.858 \\
0.847 \\
0.869 \\
0.799 \\
0.739 \\
0.789\end{array}$ & 0.924 & 0.926 & 0.924 & 0.669 & $\begin{array}{l}2.505 \\
3.993 \\
3.417 \\
4.713 \\
3.433 \\
1.976\end{array}$ \\
\hline Innovative performance (IP) & $\begin{array}{l}\text { IP1 } \\
\text { IP2 } \\
\text { IP3 } \\
\text { IP4 }\end{array}$ & $\begin{array}{l}0.861 \\
0.852 \\
0.829 \\
0.908\end{array}$ & 0.921 & 0.922 & 0.921 & 0.745 & $\begin{array}{l}2.642 \\
3.101 \\
3.042 \\
3.860 \\
\end{array}$ \\
\hline Production performance (PP) & $\begin{array}{l}\text { PP1 } \\
\text { PP2 } \\
\text { PP3 }\end{array}$ & $\begin{array}{l}0.882 \\
0.928 \\
0.933\end{array}$ & 0.941 & 0.942 & 0.941 & 0.843 & $\begin{array}{l}4.203 \\
4.827 \\
4.174\end{array}$ \\
\hline Market performance (MP) & $\begin{array}{l}\text { MP1 } \\
\text { MP2 } \\
\text { MP3 }\end{array}$ & $\begin{array}{l}0.829 \\
0.881 \\
0.893\end{array}$ & 0.901 & 0.903 & 0.902 & 0.754 & $\begin{array}{l}2.163 \\
4.558 \\
3.851\end{array}$ \\
\hline Financial performance (FP) & $\begin{array}{l}\text { FP1 } \\
\text { FP2 } \\
\text { FP3 }\end{array}$ & $\begin{array}{l}0.914 \\
0.823 \\
0.765\end{array}$ & 0.874 & 0.883 & 0.877 & 0.704 & $\begin{array}{l}2.942 \\
2.995 \\
1.888\end{array}$ \\
\hline
\end{tabular}

recently been a criticism of the criteria, as it is considered less reliable to assess discriminant validity in common research situations. Henseler et al. (2016) have suggested an alternative approach to assess discriminant validity by using heterotrait-monotrait (HTMT) correlation ratios. If the HTMT value is smaller than 1 , then there is no problem with discriminant validity (Henseler et al., 2015). All HTMT values shown in Table 2, indicating that the discriminant validity requirements have been met.

To assessment of composite models, also it is recommendable to assess the variance inflation factor (VIF) of the indicators, if VIF values much higher than one, indicate that multicollinearity might play a role (Henseler et al. 2016). From the tabulation in Table 1, it can be seen that the measurement result of latent variable construct had high reliability. Based on the test result of convergent validity, discriminant validity, and composite reliability, it can be seen that indicator used to measure a latent variable (construct) was already valid and reliable.

\section{Evaluation of structural models (inner model)}

To evaluate the model fit, data was tested by examining the standardized root mean square residual (SRMR), unweighted least squares discrepancy (d_ULS) and geodesic discrepancy (d_G) (Henseler et al., 2016). Shown in Table 3, indicating that the model has a good fit.

Inner model measurement aims to test the relevance of research model. The test is done by looking at $\mathrm{R}^{2}$ value or measurement of predictive relevance $\mathrm{Q}^{2}$. A Model is said to be relevant (feasible to use) if the result of $\mathrm{Q}^{2}>0 . \mathrm{R}^{2}$ values higher than 0.2 indicate a good explanatory power of the endogenous variables of the model (Chin, 2010).

Based on the calculation of $\mathrm{R}^{2}$ and $\mathrm{Q}^{2}$ in Table 4, it can be seen that the designed model had been feasible to use. Therefore, the study hypothesis test could be conducted.

\section{Hypotheses testing}

To assess the structural model, Hair et al. (2017) suggested looking at the $\mathrm{R}^{2}$ and the corre- 
Table 2. Heterotrait-Monotrait (HTMT) Ratio

\begin{tabular}{|c|c|c|c|c|c|c|c|c|}
\hline \multirow{2}{*}{ Construct } & \multicolumn{8}{|c|}{ Heterotrait-Monotrait (HTMT) Ratio } \\
\hline & FP & MP & PP & $\mathrm{O}$ & $\operatorname{Pr}$ & M & $\mathrm{Pd}$ & IP \\
\hline IP & 0.652 & 0.746 & 0.747 & 0.755 & 0.681 & 0.733 & 0.790 & \\
\hline $\mathrm{Pd}$ & 0.628 & 0.683 & 0.647 & 0.717 & 0.760 & 0.789 & & \\
\hline M & 0.598 & 0.626 & 0.610 & 0.722 & 0.682 & & & \\
\hline $\mathrm{Pr}$ & 0.459 & 0.544 & 0.574 & 0.733 & & & & \\
\hline $\mathrm{O}$ & 0.511 & 0.574 & 0.559 & & & & & \\
\hline PP & 0.778 & 0.781 & & & & & & \\
\hline MP & 0.681 & & & & & & & \\
\hline $\mathrm{FP}$ & & & & & & & & \\
\hline
\end{tabular}

Table 3. Model fit

\begin{tabular}{|c|c|c|c|}
\hline & & & Criterion \\
\hline SRMR & 0.053 & $\begin{array}{l}< \\
<\end{array}$ & $\begin{array}{l}0.08 \\
{[0.043 ; 0.070] \text { or HI95 of SRMR }}\end{array}$ \\
\hline d_ULS & 1.651 & $<$ & {$[0.815 ; 2.063]$ or HI95 of dULS } \\
\hline d_G1 & 2.939 & $<$ & {$[0.815 ; 2.063]$ or HI95 of dULS } \\
\hline d_G2 & 2.499 & $<$ & {$[0.815 ; 2.063]$ or HI95 of dULS } \\
\hline
\end{tabular}

Table 4. $\mathrm{R}^{2}$ and $\mathrm{Q}^{2}$ tabulation for endogenous variable

\begin{tabular}{|l|c|c|}
\hline \multicolumn{1}{|c|}{ Construct } & $\mathrm{R}^{2}$ & $\mathrm{Q}^{2}$ \\
\hline Eco-organization innovation & - & - \\
\hline Eco-marketing innovation & 0.523 & 0.315 \\
\hline Eco-process innovation & 0.585 & 0.314 \\
\hline Eco-product innovation & 0.727 & 0.427 \\
\hline Innovative performance & 0.704 & 0.460 \\
\hline Production performance & 0.558 & 0.408 \\
\hline Market performance & 0.668 & 0.448 \\
\hline Financial performance & 0.616 & 0.382 \\
\hline
\end{tabular}

sponding t-values via a bootstrapping procedure with a resample of 5000 (see Figure 3).

The hypotheses test was conducted by comparing the T-statistic value with the T-table value. At significance level of $\alpha=5 \%$, T-table value was $=1.96$. A hypothesis is accepted if the T-statistic value is greater than the T-table value (Hair et al., 2017). The result of the hypotheses testing tabulation is displayed in Table 5.

\section{DISCUSSION}

Based on the test of statistic hypothesis, it can be seen that the influence of eco-organizational innovation variable was not significant on ecoproduct innovation. This was because the company management or organization (paguyuban) of marble craftsmen in Tulungagung had less participation in disseminating the information about eco-innovative products to the craftsmen. The influence of eco-organizational innovation variable was significant on eco-marketing innovation, eco-process innovation, and innovative performance. Although the respondents' answer score which was based on the average questionnaire result was 1,772 meaning that the company almost did not implement eco-organizational innovation at all, the management's role or marble craftsmen group is significant enough in increasing innovative performance. For example, they share information with their colleagues about promotion strategies and online marketing or they remind each other to provide a description that their products are legal and they do not violate environmental laws. The eco-organizational innovation which is being applied at present which is in form of information sharing about cheaper production process tools apparently is able to increase the implementation level of eco-process innovation. The role of craftsmen group which was technically and strategically inactive should be more improved because its influence is significant in improving the innovative performance of the crafts industry center. These findings are in line with the findings of the study conducted Gunday et al. (2011) and Cheng et al. (2014).

A bit different with the study conducted by Gunday et al. (2011) and Oke (2007) where the marketing innovation influences innovative performance, in this study, the influence of eco-marketing innovation is not significant on innovative 


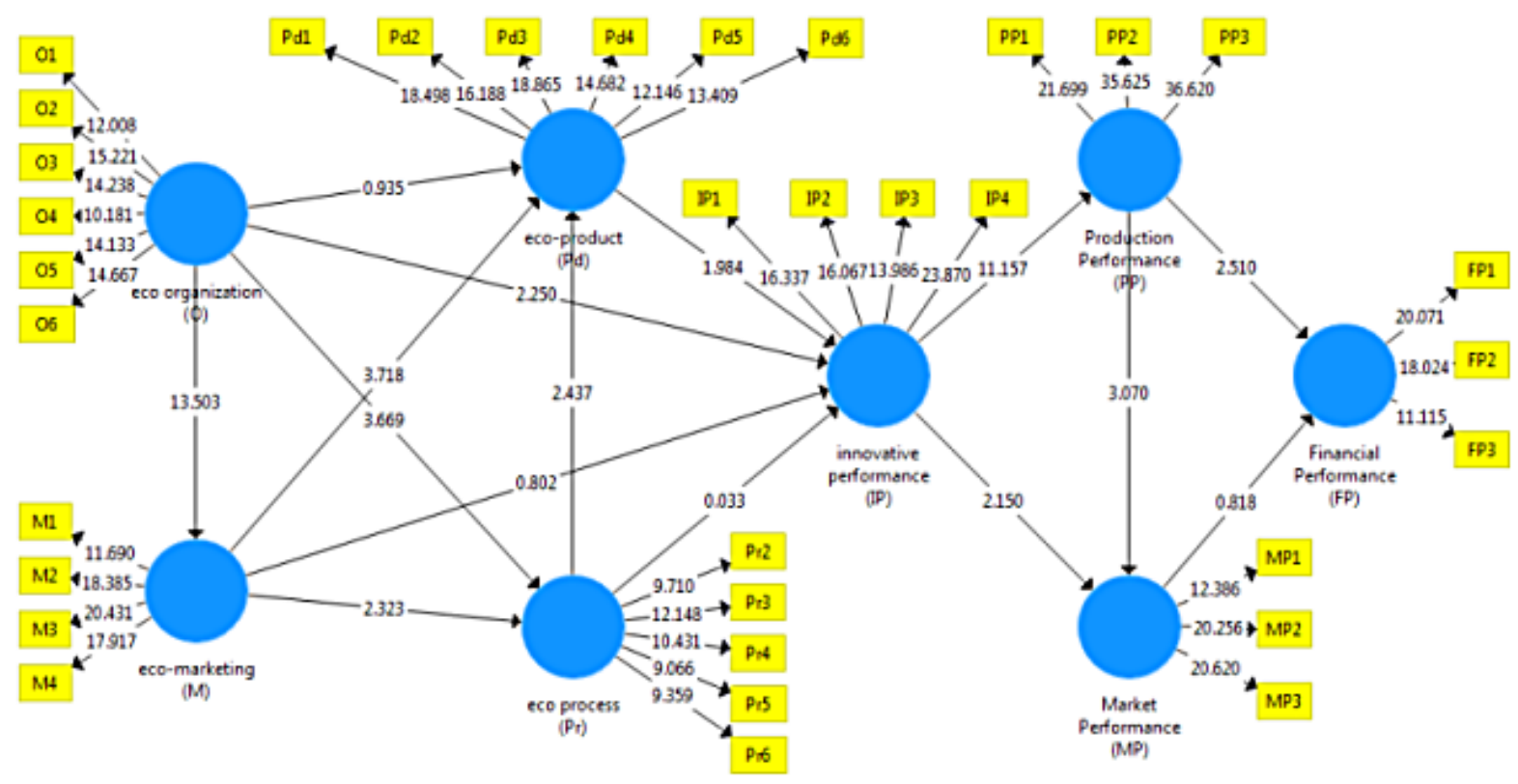

Figure 3. Bootstrapping results

Table 5. Results of the hypotheses testing

\begin{tabular}{|c|c|c|c|c|}
\hline Hypothesis & Relation & T-statistics & p-values & Decision \\
\hline H1 & $\mathrm{O} \rightarrow \mathrm{Pd}$ & 0.935 & 0.350 & not supported \\
$\mathrm{H} 2$ & $\mathrm{O} \rightarrow \mathrm{Pr}$ & 3.669 & 0.000 & supported \\
$\mathrm{H} 3$ & $\mathrm{O} \rightarrow \mathrm{M}$ & 13.503 & 0.000 & supported \\
$\mathrm{H} 4$ & $\mathrm{Pr} \rightarrow \mathrm{Pd}$ & 2.437 & 0.015 & supported \\
$\mathrm{H} 5$ & $\mathrm{M} \rightarrow \mathrm{Pr}$ & 2.323 & 0.020 & supported \\
$\mathrm{H} 6$ & $\mathrm{M} \rightarrow \mathrm{Pd}$ & 3.718 & 0.000 & supported \\
$\mathrm{H} 7$ & $\mathrm{O} \rightarrow \mathrm{P}$ & 2.250 & 0.025 & supported \\
$\mathrm{H} 8$ & $\mathrm{Pd} \rightarrow \mathrm{P}$ & 1.984 & 0.047 & not supported \\
$\mathrm{H} 9$ & $\mathrm{Pr} \rightarrow \mathrm{P}$ & 0.033 & 0.973 & supported \\
$\mathrm{H} 10$ & $\mathrm{M} \rightarrow \mathrm{P}$ & 0.802 & 0.423 & supported \\
$\mathrm{H} 11$ & $\mathrm{P} \rightarrow \mathrm{MP}$ & 2.150 & 0.032 & supported \\
$\mathrm{H} 12$ & $\mathrm{P} \rightarrow \mathrm{PP}$ & 11.157 & 0.000 & supported \\
$\mathrm{H} 13$ & $\mathrm{PP} \rightarrow \mathrm{MP}$ & 3.070 & 0.012 & not supported \\
$\mathrm{H} 14$ & $\mathrm{PP} \rightarrow \mathrm{FP}$ & 2.510 & 0.413 & \\
$\mathrm{H} 15$ & $\mathrm{MP} \rightarrow \mathrm{FP}$ & 0.818 &
\end{tabular}

performance. In line with Oslo Manual (OECD, 2005), eco-marketing innovation has a significant positive effect on eco-product innovation and ecoprocess innovation. Marketing innovation which is implemented in the marble and natural stone handicraft industry center in Tulungagung using online media has successfully reached the wider market, even penetrating the global market. The demands of a more environmentally-conscious global market, have influenced the product design of more natural and minimalist such as many produced nowadays, making the production process simpler, more efficient and it saves more expense. However, the applied eco-marketing innovation apparently has not succeeded to boost the sales amount which makes the influence is not significant on innovative performance. Online promotion and marketing are not supported with ade- quate physical outlet or showroom. There has not been an integrated information center about the potential of the marble and natural stone industry in Tulungagung, has made difficult for prospective buyers. Many buyers complained about the marble industry craftsmen's and various products made from natural stone that spread without any product information's center that can guide potential investors, traders, and tourists. This condition is causing, the results of this study do not support the study hypothesis of $\mathrm{H} 10$.

In line with the findings of the study conducted by Bigliardi \& Dormio (2009); Raymond \& St-Pierre (2010); Maine et al. (2012), Gunday et al. (2011) and Cheng et al. (2014), eco-process innovation has significant positive effect on ecoproduct innovation. With the increase of craftsmen's ability to create their own simpler and cost- 
safe new machining tools, the type of product that can be made becomes more varied according to the buyer's demand. The eco-process innovation which is related to the delivery process of a product or raw material is still constrained by the fact that there has not been any cargos terminal or container's company so that it makes the delivery process cannot be done anytime. This has led to the fact that even though eco-process innovation has the significant influence on eco-product innovation, it does not have the significant influence on innovative performance.

Eco-product innovation has the significant effect on innovative performance. The types of product produced in creative industries center of marble and natural stone mostly depend on buyers' request. The global market demand which is more eco-innovative has been successfully pushing the craftsmen to create eco-innovative products. The craftsmen's ability in the production process has been increasing the products' amount and variation which finally can improve innovative performance. This finding is in line with the finding of the study conducted by Oke (2007) and Gunday et al. (2011).

Like the findings of the study conducted by Koufteros \& Marcoulides (2006), Liu et al. (2009), Peters (2006) and Gunday et al. (2011), innovative performance variable has significant positive influence on production performance and market performance. The innovative performance improvement which is measured by increased ability to introduce new products to the market, improvement on ability of production process; and the increase of new products apparently is able to improve production performance (product quality improvement, ability in providing products amount based on consumers' demand, production speed and product delivery) and market performance (the increase of costumers' satisfaction, total sales and market).

A bit different with the study conducted by Gunday et al. (2011) where the production performance does not influence financial performance, in this study, the production performance has significant positive influence on financial performance (return on sales, return on assets and general profit) or support the study hypothesis. This finding is in line with the findings of the study conducted by González-Benito (2005), Li (2005) and $\mathrm{Li}(2000)$. In contrast to other studies, in this study, market performance has no significant ef- fect on financial performance. Based on the respondents' opinion, the average rate of successful financial performance over the last 3 years is considered to be less successful even though improvement of the innovative performance and production performance are quite successful. This is because the price and expenses on the raw material are getting high while the sale price is stable and some even decrease.

\section{CONCLUSIONS}

From this study, it can be concluded that ecoinnovation variables which significantly influence the innovative performance in the creative industries center of marble and natural stone crafts in Tulungagung are eco-product innovation with T-statistic of 1.984 and eco-organizational innovation with T-statistic of 2.250. Eco-innovation variables which do not have the significant influence on innovative performance in creative industries center of marble and natural stone in Tulungagung are eco-marketing innovation variable with T-statistic of 0.802 and eco-process innovation variable with T-statistic of 0.033 .

Innovative performance variable significantly has a positive influence on production performance with T-statistic of 11.157 and market performance with T-statistic of 2.150. Production performance variable significantly influences market performance with T-statistic of 3.070 and financial performance with T-statistic of 2.510. Market performance variable not significantly influences financial performance with T-statistic 0.818 .

Thus, innovative performance in creative industries center of marble and natural stone in Tulungagung will increase if the implementation level of eco-organizational innovation and ecoproduct innovation are improved. Improving the implementation of eco-process innovation and eco-marketing innovation even though it does not directly improve the innovative performance, but through the improvement of eco-product innovation will be able to improve innovative performance. Improvement of innovative performance will significantly improve production performance and market performance and ultimately will improve financial performance. However, improved market performance does not significantly affect financial performance. 


\section{Acknowledgement}

The authors thankfully acknowledge the financial support from Directorate of Research and Community Service (DRPM), Directorate General for Research and Development, Ministry of Research, Technology and Higher Education, Republic of Indonesia.

\section{REFERENCES}

1. Bigliardi, B., Dormio, A.I. 2009. An empirical investigation of innovation determinants in food machinery enterprises. European Journal of Innovation Management, 12(2), 223-242.

2. Birkinshaw, J., Hamel, G., Mol, M.J. 2008. Management Innovation. Academy of Management Review, 33(4), 825-845.

3. Cheng, C.C.J., Yang, C.L., Sheu, C. 2014. The link between eco-innovation and business performance: A Taiwanese industry context. Journal of Cleaner Production, 64, 81-90.

4. Chin, W. 2010. How to write up and report PLS analyses, in Esposio, V., Chin, W., Henseler, J., and Wang, H. (Eds.). Handbook of partial least squares: Concepts, methods and applications. Berlin, Germany: Springer, 655-690.

5. Díaz-García, M.C., Moreno, Á.G., Saez-Martinez, F.J. 2015. Eco-innovation: Insights from a literature review. Innovation: Management, Policy and Practice, 17(1), 6-23.

6. Dijkstra, T.K. 2010. Latent Variables and Indices: Herman Wold's Basic Design and Partial Least Squares, in Handbook of Partial Least Squares: Concepts, Methods and Applications (Springer Handbooks of Computational Statistics Series, vol. II), V. Esposito Vinzi, W.W. Chin, J. Henseler and H. Wang (Eds), Springer: Heidelberg, Dordrecht, London, New York, pp. 23-46.

7. Dijkstra, T.K. 2014. PLS' Janus Face - Response to Professor Rigdon's 'Rethinking Partial Least Squares Modeling: In Praise of Simple Methods', Long Range Planning, 47(3), 146-153.

8. Dijkstra, T.K., Henseler, J. 2015. Consistent Partial Least Squares Path Modeling, MIS Quarterly, 39(2), 297-316.

9. Ettlie, J.E., Reza, M.E. 1992. Organizational Integration and Process Innovation. Academy of Management Journal, 35(4), 795-827.

10. Fornell, C., Larcker, D.F. 1981. Evaluating Structural Equation Models with Unobservable Variables and Measurement Error. Journal of MarketingResearch, Vol. 18(No. 1), 39-50.

11. González-Benito, J. 2005. A study of the effect of manufacturing proactivity on business performance. International Journal of Operations \& Production Management, 25(3), 222-241.

12. Gunday, G., Ulusoy, G., Kilic, K., Alpkan, L. 2011. Effects of innovation types on firm performance. International Journal of Production Economics, 133(2), 662-676.

13. Hagedoorn, J., \& Cloodt, M. 2003. Measuring innovative performance: is there an advantage in using multiple indicators? Research Policy, 32(8), 1365-1379.

14. Hair, J.F., Hult, G.T M., Ringle, C.M., Sarstedt, M. 2017. A Primer on Partial Least Squares Structural Equation Modeling. 2nd Ed. Thousand Oaks: Sage.

15. Henseler, J., Sarstedt, M. 2013. Goodness-of-Fit Indices for Partial Least Squares Path Modeling, Computational Statistics, 28(2), 565-580.

16. Henseler, J., Hubona, G., Ray, P.A. 2016. Using PLS path modeling in new technology research: updated guidelines. Industrial Management \& Data Systems, 116(1), 2-20

17. Henseler, J., Ringle, C.M., Sarstedt, M. 2015. A new criterion for assessing discriminant validity in variance-based structural equation modelling. Journal of the Academy of Marketing Science, 43(1), 115-135.

18. Horbach, J. 2008. Determinants of environmental innovation-New evidence from German panel data sources. Research Policy, 37(1), 163-173.

19. Hu, L.T., Bentler, P.M. 1998. Fit indices in covariance structure modeling: Sensitivity to underparameterized model misspecification. Psychological Methods, 3(4), 424-453.

20. Kemp, R., Arundel, A. 1998. Survey Indicators for Environmental Innovation. Indicators and Data for European Analysis (IDEA) Project Report Series, $1-26$.

21. Kemp, R., Pearson, P. (2007). Final report MEI project about measuring eco-innovation. UM Merit, Maastricht, 32(3), 121-124.

22. Kotler, P., Wong, V., Saunders, A.J., \& Armstrong, G. 2013. Principles of Marketing. Pearson education, Vol. 53.

23. Koufteros, X., Marcoulides, G.A. 2006. Product development practices and performance: A structural equation modeling-based multi-group analysis. International Journal of Production Economics, 103(1), 286-307.

24. Li, L. 2000. An analysis of sources of competitiveness and performance of Chinese manufacturers. International Journal of Operations and Production Management, 20(3-4), 299-315.

25. Li, L. 2005. Views 20 CrossRef citations 0 Altmetric Original Articles Assessing intermediate infrastructural manufacturing decisions that af- 
fect a firm's market performance. Journal International Journal of Production Research, 43(12), 2537-2551.

26. Liu, Y., Li, Y., Wei, Z. 2009. How organizational flexibility affects new product development in an uncertain environment: Evidence from China. International Journal of Production Economics, 120(1), 18-29.

27. Maine, E., Lubik, S., Garnsey, E. 2012. Process-based vs. product-based innovation: Value creation by nanotech ventures. Technovation, 32(3-4), 179-192.

28. Mcaloone, T.C., Hare, J.O. 2014. Eco - innovation in small to medium sized enterprises : needs and opportunities for action.

29. Miedzinski, M., Doranova, A., Castel, J., Roman, L., Charter, M. 2013. A guide to eco-innovation for SMEs and business coaches. Brussels.

30. Murphy, J., Gouldson, A. 2000. Environmental policy and industrial innovation: integrating environment and economy through ecological modernisation. Geoforum, February, 31(1), 33-44.

31. Negny, S., Belaud, J.P., Robles, G.C., Reyes, E.R., Ferrera, B. 2012. Toward an eco-innovative method based on a better use of resources: application to chemical process preliminary design. Journal of Cleaner Production, 32, 101-113.

32. O'Hare, J.A., McAloone, T.C., Pigosso, D.C.A., Howard, T.J. 2014. Eco-Innovation Manual: Work- ing version for Pilot Application.

33. OECD. 2005. Oslo Manual - Inglês - Terceira Edição. Communities (Third edit.).

34. Oke, A. 2007. Innovation types and innovation management practices in service companies. International Journal of Operations \& Production Management, 27(6), 564-587.

35. Peters, B. 2008. Innovation and Firm Performance: An Empirical Investigation for German firms. Working Paper, Center for European Economic Research, Mannheim, Germany.

36. Pujari, D. 2006. Eco-innovation and new product development: Understanding the influences on market performance. Technovation, 26(1), 76-85.

37. Raymond, L., St-Pierre, J. 2010. R\&D as a determinant of innovation in manufacturing SMEs: An attempt at empirical clarification. Technovation, 30(1), 48-56.

38. Reid, A., Miedzinski, M. 2008. Eco-innovation. Final report for sectorial innovation watch. Technopolis, May, 1-78.

39. Tessitore, S., Daddi, T., Iraldo, F. 2010. Eco-innovation and economic performance in industrial clusters: Evidence from Italy. World Academy of Science, Engineering and Technology, 42, 1487-1493.

40. Vinzi, V.E., Chin, W.W., Henseler, J., Wang, H. (Eds). 2010. Handbook of Partial Least Squares. Springer-Verlag, Berlin Heidelberg. 